\title{
INTRODUCTION: THE JAMES JOYCE TRANSLATION DOSSIER ${ }^{1}$
}

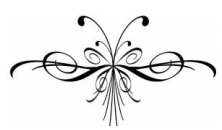

JOLANTA WAWRZYCKA

The essays in the present dossier illustrate the extent to
which James Joyce's writing interrogates language, as they
put to question claims to univocality and transparency. At the heart of Joyce's artistic endeavor is the notion of writing-as-translation; Joyce explodes the English he received in the course of his rigorous Jesuit education. His early linguistic training and translation exercises fostered in him a performative engagement with language(s) and eventually engendered artistic language that is a polylogue of (inter)textual, linguistic and sociocultural currents that emerges in the early twentieth century. And whereas Joycean criticism has become an "industry" in its own right, the commentary by the translators who have made, and continue making, Joyce's oeuvre available in almost all languages is yet to be brought together. This dossier is but a sample of translatorial scholarship on Joyce, but one envisions a multilingual collection of forewords, pronouncements, introductions, and essays penned by the many Joyce translators whose collective wisdom is, for now, dispersed across languages and libraries and all but hidden from the community of translators and readers at large.

In the field of Joyce translation studies, Fritz Senn of the Zurich James Joyce Foundation has been the most prolific translatorial reader, making reading-as-translation one of the central currents in his scholarship, help-

${ }^{1}$ This project evolved over some time now and a number of people have been very helpful along the way: Christine van Boheemen, Fritz Senn and especially Rosa Maria Bosinnelli with whom I shared many translation panels at the Joyce symposia and conferences in Tulsa 2003, Dublin 2004, Budapest 2006, Austin 2007, and Tours in 2008. I'm grateful for support to Rosemary F. Guruswamy and Paul Witkowsky. Very special thanks go to Gustavo Althoff. 
ing to forge the discipline, and influencing a whole generation of Joyce scholars throughout the world. In 1967 Senn pointed out that thousands of "readers who do not know English have 'read' Ulysses when in fact they have not been exposed to a single word as Joyce wrote it", ${ }^{2}$ and thus touched upon the very core of what translation does: it pulls a plug on signifiers in one language without any promise of seamlessly re-plugging them in another. But still, translation and translation studies flourish. The proliferation in recent decades of literature on the subject of translation theory and practices speaks to the relevance if not urgency of this ancient discipline. ${ }^{3}$

Post-colonial developments in translation studies have revolutionized the very notion of translation, not only by, for example, re-examining the concept of the "original" vis-à-vis the translation of that original - the former presumed to be "superior" to its mere "copy" - but also by exploding the range of the term to consider questions of representation, power and historicity. Susan Bassnett notes that "colonialism and translation went hand in hand", and that different groups in the colonization process understood translation in different terms:

The notion of the colony as a copy or translation of the great European Original inevitably involves a value judgment that ranks the translation in a lesser position in the literary hierarchy. The colony, by this definition, is therefore less than its colonizer, its original. ${ }^{4}$

It is a tired cliché that something always gets lost in translation; Salman Rushdie adds that "something can also be gained". ${ }^{5}$ This gain is apparent in

${ }^{2}$ Fritz Senn, “The Issue is Translation”, James Joyce Quarterly, Vol. 4, no. 3: 163, and Joyce's Dislocutions. Essays on Reading as Translation, ed. John Paul Riquelme (Johns Hopkins University Press, Baltimore and London, 1984), p. 4.

${ }_{3}$ Such publications as Theories of Translation: An Anthology of Essays from Dryden to Derrida, ed. Rainer Schulte and John Biguenet (Chicago: University Press of Chicago, 1992) and The Translation Studies Reader, ed. Lawrence Venuti(London: Routledge, 2000), can be considered classics for translation scholars in the English language. They have been joined by such positions as Bassnett/Trivedi (see note 4) and Translation - Theory and Practice, ed. Daniel Weissbort and Ástráđur Eysteinsson (Oxford: Oxford University Press, 2006).

${ }^{4}$ Susan Bassnett and Harish Trivedi, "Introduction: Of Colonies, Cannibals and Vernaculars," in Post-Colonial Translation: Theory and Practice, ed. Susan Bassnett and Harish Trivedi (Routledge, London, 1999), p. 4.

${ }^{5}$ Salman Rushdie, Imaginary Homelands (New Delhi: Penguin and Granta, 1991), p. 17.

Scientia Traductionis, n.8, 2010 
the pollinated and enriched language (and culture) that results from the act of translation - this act not just of bearing across but of fertile coming together. Thus it is not only in the case of Indo-British writers but in that of all Indian English writers that the texts they create are 'translated', the very act of their writing being one of translation. ${ }^{6}$

The present dossier is divided into two parts. In Section One, "Translators' Workshops," contributors offer descriptive rather than evaluative discussions of translatorial choices, priorities, sacrifices and interpretations. Two scholars who work on Joyce in Italian and Hungarian focus on comparative close readings of translations. Serenella Zanotti's "By Way of France: Joyce's Translations into Italian" advances and illustrates the thesis that the early reception of Joyce in Italy was heavily influenced by the French translations of the mid- and late 1920s. Zanotti's research compares fragments of Ulysses published by Rossi in 1930 with Guido de Angelis's magisterial 1960 Ulisse and with Bona Flecchia's 1995 text. Her discussion focuses on particular slang expressions, colloquialisms, and on daring inventive linguistic departures designed to sever translations' ties with their French roots.

The work of Marianna Gula is a part of an ambitious translatorial team project that is underway in Hungary to re-edit and re-translate the existing Hungarian versions of Ulysses. Marianna Gula is one of the team members and here she presents a quasi-duologue with Fritz Senn, whose approach to translation informs Gula's own translator's workshop. Her essay, "Lost a Bob but Found a Tanner: From a Translator's Workshop", addresses the need to apply a global method to the Joyce text that she describes as transference of functions and effects. In the face of the inevitable losses that translating Ulysses entails, Gula's priority as a translator is "the work of salvage" and the "removal of debris" introduced by the earlier translators.

Part Two, "Translators' Lens: Lestrygonians," is a game of sorts, originally proposed by Fritz Senn; it is based on a series of multilingual close readings of the "sandwich passage" of the Lestrygonians Chapter of Ulysses. While issues of domestication-alienation of the translated text loom large within or behind or beyond or above these essays, the goal is to trace how the texture of Bloom's associative thinking fares in other languages - for instance: how Joyce's Hiberno-English syntactic/semantic register travels in translation; how translators handled word play, paronomasia, lexical handicaps, repetition, quotations, sound effects, semantic overlays, and ambigui-

${ }^{6}$ G.J.V. Prasad, "The strange case of the Indian English novel," in Bassnett and Trivedi, p. 41. 
ties. As the essays illustrate, this rich passage puts translators on alert for biblical echoes, for cultural overtones and allusions, and for linguistic games both within the passage/episode and throughout Ulysses.

The section opens with Scarlett Baron's Flaubertian close-ups that reveal new aspects of Joyce's transcreative approach to language (cf. Bosinelli below). In "The Place where Bloom is in the Restaurant: French Translations of Ulysses" Baron highlights contextual and programmatic differences between Morel's 1929 and Aubert's 2004 team translations. Her essay all but indicts some of the editorial decisions by Aubert, such as assigning eight translators to various episodes, or retaining Morel's original translation of Oxen of the Sun. But Aubert's emphasis on updating the language of the new Ulysses allows Baron to present some insightful comparative readings as she moves on to discuss the "sandwich passage".

Next, Erika Mihálycsa in her essay "Translators Up the (Plum) Tree: (Food)Notes on Lestrygonians in Hungarian and Romanian" presents an ambitious reading of one Romanian and two Hungarian translations of the "sandwich passage" and offers comparative close-ups of the mechanisms of (un)translatability: language games that exploit homonymy and polysemy, literal and figurative readings of idiomatic constructions, and language effects that unveil textual tensions.

My own contribution, "Sandwich on a Mission: Polytropic Vagaries in Ulysses," looks briefly at the origins of the word "sandwich" and its migration into most European languages (with minor, language-specific adjustments in orthography). Comparative readings of the Polish, Russian, and two Czech renditions of the "sandwich passage" highlight translation hindrances posed by Slavic languages that often necessitate interpretive solutions.

The question of what is lost in translation is undertaken by Ástráđur Eysteinsson in "Concocting a Sandwich in Lestrygonians: Icelandic Ulysses". Partly a tribute to the Icelandic translator of Ulysses, Sigurður Magnússon, the essay playfully points out the larger dynamics of translation that involve inter-cultural negotiation and even compensation for referents that cannot be accommodated in target languages. Icelandic examples of (un)translability alert readers to "the ways in which translation can be, and should be, a creative dialogue between two cultures and between two writers who, to stick to the dietetic and culinary focus of Lestrygonians, ultimately cook together the meal that readers of translation are served".

The coda of this dossier comes from Rosa Maria Bosinelli, whose work, like Fritz Senn's, has paved the way for a great number of Joycetranslation scholars on both sides of the Atlantic. Bosinelli's most recent in- 
terests in translation theory include postcolonial studies and analyses of language/culture/identity. Although no foreign language is involved in Bosinelli's discussion, she emphasizes the intralingual, translatorial-cumtranscreative nature of Joyce's "writing as translation". Such writing requires "reading as translation". When Fritz Senn reminds us that "Ithaca is written in abstract Latinate language and is mentally processed for our understanding via a translation into standard English", he adds:

I can see Joyce taking his revenge on the colonizers, turning the tables upon them, writing better English than they could and also offering them a diction that is above their understanding".

In this context, Joyce's transcreated English acquires palimpsestic dimensions as it inscribes and defies the socio-linguistic positioning of the Irish. Post-colonial practice of questioning language and signification points toward a much broader understanding of the term "translation". Transcreation is one of the many terms used by Haroldo de Campos, for whom the term "translation" acquired varied lexical identities as it morphed into "transhellenization" when he worked on translating Homer into Brazilian Portuguese; into "translumination" and "transparadisation" when he worked on Dante; into "transluciferation" when Goethe's Faust was involved; into "reimagination" when he worked on classical Chinese poetry; or into "poetic reorchestration" when he was translating the Hebrew Bible. ${ }^{8}$ De Campos's nomenclature is highly revealing and, as noted by Else R. P. Vieira,

some of the neologisms coined by Haroldo de Campos (...) offer a vanguardist poetics of translation as textual revitalization while pointing to the Anthropophagic dimension of feeding on the very text he is translating to derive his metalanguage. "Re" and "trans" are recurrent prefixes that locate translation at a remove from monological truth in the direction of a transformative recreation of inherited tradition. (96-97)

De Campos' playful neologisms open some broad vistas for further neologising - "transgermanization" or "transpolonization" - and, in terms of translation as transformative recreation of a source text, the essays in this volume take up that challenge. They interrogate the practical problems that

7 Senn's emphasis. See his Joycean Murmoirs, ed. Christine O’Neill (Dublin: The Lilliput Press, 2007), p. 82.

8 De Campos had also coined such terms as "transtextualization" and "translumination." See Else Ribeiro Pires Vieira, "Readings of Antropofagia and Haroldo de Campos' Poetics of Transcreation" in Bassnett and Trivedi, pp. 96.

Scientia Traductionis, n.8, 2010 
fall under the category of Jakobsonian interlingual translation, that is, the process of "interpretation of verbal signs by means of signs of some other language" (which Jakobson calls "translation proper"); they illustrate interpretive strategies of "re-languaging" or "trans-semantification" (that aim at scrupulous re-fostering the work's very literariness and the Ingardenian polyphonic harmony of its aesthetically relevant strata); ${ }^{10}$ and they consider the post-colonial concept of "cannibalistic translation", a metaphor for what translators "can do with a text" and likened by de Campos to "a blood transfusion, where the emphasis is on the health and nourishment of the translator". ${ }^{11}$ De Campos' metaphor signals a new redistribution of power in the original/copy relationship and represents, as Bassnett and Trivedi put it,

a far cry from the notion of faithfulness to an original, of the translator as servant of the source text. Translation, according to de Campos, is a dialogue, the translator is an all-powerful reader and a free agent as a writer. This is a vastly different view of translation from that described by George Steiner12 as involving the 'penetration' of the source text. (5)

But as Fritz Senn reflects in his richly-woven chapter of Joycean Murmoirs devoted to language/translation, metaphors and theories of translation, abundant as they are, have yet to prove their usefulness to translators (81-106). Always fascinated with language and what Joyce can do with it, Senn notes that 'Joyce wrote more and more 'foreign' English and showed that every language is also foreign up to a point. He increasingly exposed English as a foreign language" (82). Senn believes that whereas non-native speakers are perennially handicapped as they work in a second, acquired language, they have an advantage over the native speakers in that they never really take words for granted - they "see language probably before they see anything else" (82). For that reason, translators are the ultimate closereaders, and it is through their hypolectic translatorial doings, fraught as they are with compromises, missives, excesses, and approximations - balanced by masterful solutions - that we can, in Senn's words, "admire what has been

9 Roman Jakobson, "On Linguistic Aspects of Translation, in Theories of Translation, ed. Rainer Schulte and John Biguenet (Chicago: University of Chicago Press, 1992, pp. 14451) p. 145.

10 See Roman Ingarden, "On Translations," trans. Jolanta Wawrzycka, in Analecta Husserliana, XXXIII (Kluwer Academic Publishers, 1991, pp. 131-192), p. 139, 144.

11 See "Introduction: Of Colonies, Cannibals and Vernaculars" in Bassnett and Trivedi, p. 5 .

12 George Steiner, After Babel. Aspects of Language and Translation (Oxford: Oxford University Press, 1975), p. 271. 
done, against tremendous odds, and how many windows onto foreign cultures translators have brilliantly opened" (89).

Jolanta Wawrzycka jolanta@radford.edu Radford University 